Mathématiques et sciences humaines
Mathematics and social sciences

193 | Printemps 2011

Varia

\title{
Marc Barbut et l'Espagne
}

Marc Barbut and Spanish statistics

Jose-Maria Arribas

\section{CpenEdition}

\section{Journals}

Édition électronique

URL : http://journals.openedition.org/msh/11944

DOI : $10.4000 /$ msh. 11944

ISSN : 1950-6821

\section{Éditeur}

Centre d'analyse et de mathématique sociales de l'EHESS

\section{Édition imprimée}

Date de publication : 15 janvier 2011

Pagination : 7-18

ISBN : 09876936

ISSN : 0987-6936

\section{Référence électronique}

Jose-Maria Arribas, " Marc Barbut et l'Espagne », Mathématiques et sciences humaines [En ligne], 193| Printemps 2011, mis en ligne le 07 juin 2011, consulté le 23 juillet 2020. URL : http://

journals.openedition.org/msh/11944; DOI : https://doi.org/10.4000/msh.11944

Ce document a été généré automatiquement le 23 juillet 2020.

(c) École des hautes études en sciences sociales 


\title{
Marc Barbut et l'Espagne
}

\author{
Marc Barbut and Spanish statistics
}

\author{
Jose-Maria Arribas
}

\section{RÉSUMÉS}

Les premiers souvenirs de Marc Barbut sur l'Espagne remontent à 1936, quand il était enfant. C'était le début de la Guerre Civile, un événement qui avait arrêté le développement de la statistique espagnole alors qu'elle avait déjà une certaine reconnaissance internationale. Le développement de la statistique mathématique espagnole avait commencé au début des années 1920, au milieu d'une conjoncture très favorable, grâce au statut de neutralité de l'Espagne durant la première guerre mondiale. C'est dans ce contexte que se produit le mouvement de rénovation de la mathématique espagnole impulsé par R. Pastor et l'intérêt pour la statistique mathématique. En 1931, l'année de la proclamation de la Seconde République, l'Institut International de la Statistique (IIS), célèbre déjà sa vingtième session dans un Madrid républicain, et des personnalités de la statistique internationale y assistent.

M. Barbut commence à visiter l'Espagne pour des questions professionnelles en 1967, au moment où la société espagnole commence à changer très rapidement. Il est invité par le professeur T. Ibern au Département de statistique de l'Université de Barcelone. En février 1997, M. Barbut commence sa participation aux colloques de Statistique et Sociologie organisés par l'Universidad Nacional de Educacion a Distancia (UNED), le Centre de recherche sociologique espagnol (CIS), la Casa Velázquez, l'Institut National de la Statistique, INE, et d'autres institutions comme l'Association espagnole pour l'Histoire de la Statistique et de la Probabilité (AHEPE). Toutes ces activités académiques furent reconnues par les statisticiens et sociologues espagnols en 2005 quand il fut nommé docteur " honoris causa " à l'UNED sur la proposition de la Faculté de Sciences Politiques et Sociologie. 
M. Barbut's first memories of Spain come from his childhood, in 1936. At that time, the beginning of the Spanish Civil War stopped the development of Spanish Statistics, and some of the institutions created a few years earlier disappeared. Nevertheless, Spanish Statistics had already reached a certain international recognition, as is shown by the 20th IIS meeting, which took place in the republican Madrid in 1931. This new statistical movement had its origins both in the Spanish mathematical renovation inspired by Rey Pastor, and in favorable conditions for new academic institutions during the 1920s, due to the neutral position of Spain in the First World War.

The first time M. Barbut made a professional visit to Spain was in 1967, a period in which Spanish society was changing very quickly. He was invited by Torras Ibern, a professor of Statistics from the University of Barcelona. In 1997, when Spanish democracy was already consolidated, M. Barbut began his collaborations with many Spanish institutions: "Spanish University for Distance Education" (UNED), "Spanish Centre for Social Research" (CIS), the French cultural institution "Casa de Velázquez", the "National Institute of Statistics" (INE), and the "History of Statistics and Probability Spanish Association" (AHEPE). His academic career and activity as a whole, deserving the acknowledgment of Spanish community of sociologists and statisticians, was awarded by a "Honorary Degree" in the UNED in 2005.

\section{INDEX}

Mots-clés : histoire de la statistique, Marc Barbut, statistique en Espagne, statistique et sociologie

Keywords : history of statistics, Marc Barbut, sociology and statistics, statistics in Spain

\section{AUTEUR}

JOSE-MARIA ARRIBAS

Facultad de Ciencias Politicas y Sociologia, Universidad Nacional de Educacíon a Distancia (UNED), Madrid, jarribas@poli.uned.es 